\title{
CHARACTERIZATION OF LIGHTWEIGHT LIME MORTARS CONTAINING BRICK WASTE POWDER
}

\author{
MARTIN VYŠVAřIL*, TOMÁŠ ŽIŽLAVSKÝ, PATRIK BAYER, \\ PAVla RovNANíKOVÁ
}

\author{
Brno University of Technology, Faculty of Civil Engineering, Veveři 331/95, 602 00 Brno, Czech Republic \\ * corresponding author: vysvaril.m@fce.vutbr.cz
}

\begin{abstract}
This work deals with the effects of an expanded perlite (EP) on the hardened properties of air lime mortars with a $50 \%$ brick waste powder content. The influence of different substitution of quartz sand by EP is also monitored here. A relationship between EP content and physical-mechanical properties of mortar (flexural and compressive strength, pore system) and mortar frost resistance has been found. Very good contact between the binder matrix and EP surface was observed in microstructural images of mortars that conclusively exhibits the formation of products by pozzolanic reaction on the surface of EP. This work could be helpful for the establishment of the essential proportions of EP and quartz sand to be used in air lime mortars designed for restoration works.
\end{abstract}

KEYWORDS: Lightweight mortar, lime, brick powder, perlite, strength, porosity, frost resistance.

\section{INTRODUCTION}

Lightweight aggregates are used in plasters to improve their acoustic and thermal insulation, or fire resistance 17[5]. Lessening the density of mortars often causes a strength reduction and porosity enhancement, which limits the utilization of the mortar. Expanded perlite, expanded clay, expanded glass, and hollow microspheres are lightweight materials that are pozzolan active and can therefore afford additional advantages in mortars by improving their mechanical properties. Nowadays, expanded perlite (EP) is used as a component of lightweight cement or lime-cement pre-mixed coating mortars fulfilling today hygrothermal requirements on buildings performance [6. These materials are usually hydrophobized, consequently they show worse properties in the comparison with traditional lime mortars, mainly a limited moisture transport to the plaster surface. Application of these renovation mortars led to the shift of level of capillary rise above the renovated part of masonry [7, [8. Recently, the application of EP in air lime mortars proposed for restoration works was reported 911].

In this work, the influence of EP on the mechanical properties, microstructure and frost resistance of lime-brick powder mortars are investigated. Waste brick powder was used to improve the strength characteristics of lime mortar as a cement replacement due to the suppose applications of mortars in restoration works. It has previously been found that waste brick powder from skiving of heat-insulating brick is a material with very good pozzolanic properties and it has a great potential in lime mortars production [12. According the latest results, the combination of $\mathrm{EP}$ and waste brick powder in lime mortars seems to be auspicious [13, 14].

\section{MATERIALS AND EXPERIMENTAL PROCEDURES}

Commercial lime CL 90-S supplied by Carmeuse Czech Republic, Ltd. was used to prepare mortar samples. The brick waste powder from the HELUZ Brickworks factory, v.o.s. located in Hevlín (Czech Republic) was added as a pozzolanic admixture to improve the strengths and frost resistance of hardened mortars. Pozzolanic activity of the brick waste powder determined by the Chapelle test was $348 \mathrm{mg} \mathrm{Ca}(\mathrm{OH})_{2} / \mathrm{g}$ after $1 \mathrm{~d}$ treatment and $556 \mathrm{mg} \mathrm{Ca}(\mathrm{OH})_{2} / \mathrm{g}$ after $5 \mathrm{~d}$ treatment. Natural quartz sand (fraction $0 / 2 \mathrm{~mm}$ from Českomoravský štěrk, Inc., Hulín) and expanded perlite (Experlit 180, fraction 0/2 mm from Perlit, Ltd., Šenov u Nového Jičína) were used as aggregates. Some physico-mechanical properties of the EP, as imparted by the manufacturer, are summarized in figure 1 together with a granulometry of all raw materials. The chemical composition of initial materials is stated in table 1 the mineralogical composition in table 2 respectively.

The mixtures composition is given in table 3 The water:binder coefficient was different for each mixture to achieve a normal fresh mortar consistency $(160 \pm 5 \mathrm{~mm})$. The composition of mortar mixtures considers the effort to prepare the lightweight mortars with sufficient strength, so the resulting binder/aggregate volume ratios are not constant. By reason of high water absorption of dry expanded perlite, this was immersed for 24 hours in water and subsequently mixed with dry mortar components. The prismatic moulds of size $40 \times 40 \times 160 \mathrm{~mm}$ were used for casting of the mortar mixtures. Hardened mortar samples were demoulded after $48 \mathrm{~h}$ and stored at ambient temperature $\left(22 \pm 2{ }^{\circ} \mathrm{C}\right)$ and $\mathrm{RH}$ of $50 \pm 5 \%$. The mechanical properties of mortars were determined 


\begin{tabular}{lrrrrrrrrrrr}
\hline & $\mathrm{SiO}_{2}$ & $\mathrm{Al}_{2} \mathrm{O}_{3}$ & $\mathrm{Fe}_{2} \mathrm{O}_{3}$ & $\mathrm{CaO}$ & $\mathrm{MgO}$ & $\mathrm{K}_{2} \mathrm{O}$ & $\mathrm{Na}_{2} \mathrm{O}$ & $\mathrm{P}_{2} \mathrm{O}_{5}$ & $\mathrm{TiO}_{2}$ & $\mathrm{SO}_{3}$ & L.O.I. \\
\hline Lime & 0.9 & 0.7 & 0.4 & 68.1 & 1.3 & 0.5 & 0.2 & $<0.1$ & 0.1 & 0.3 & 27.9 \\
Brick powder & 57.4 & 14.6 & 5.5 & 9.8 & 4.0 & 2.8 & 1.4 & 0.1 & 0.3 & 1.2 & 0.7 \\
Quartz sand & 86.8 & 6.5 & 1.2 & 0.5 & 0.3 & 2.3 & 0.9 & $<0.1$ & 0.2 & 0.1 & 1.0 \\
EP & 68.0 & 16.0 & 1.9 & 4.5 & 0.4 & 2.5 & 4.6 & 0.1 & 0.1 & $<0.1$ & 0.3 \\
\hline
\end{tabular}

TABLE 1. Chemical composition of initial materials (mass \%).

\begin{tabular}{lcccc}
\hline Mineral & Lime & Brick powder & Quartz sand & EP \\
\hline Albite & - & 13.5 & - & 1.9 \\
Anatase & - & 2.8 & - & - \\
Anorthite & - & - & - & 3.2 \\
Biotite & - & - & 3.0 & 2.8 \\
Brucite & 0.5 & - & - & - \\
Calcite & 1.8 & - & - & - \\
Epidote & - & - & 3.6 & - \\
Hematite & - & 3.1 & 0.7 & - \\
Microcline & - & 12.4 & 3.9 & - \\
Muscovite & - & 8.9 & - & - \\
Orthoclase & - & 2.9 & 3.0 & - \\
Porthlandite & 97.1 & - & - & - \\
Quartz & - & 31.2 & 75.6 & 0.4 \\
Rutile & - & 3.1 & - & - \\
Sandine & - & 2.4 & - & 0.6 \\
Staurolite & - & - & 6.1 & - \\
Amorphous phases & - & 19.6 & 1.1 & 90.8 \\
\hline
\end{tabular}

TABLE 2. Mineralogical composition of raw materials obtained by XRD analysis (mass \%).

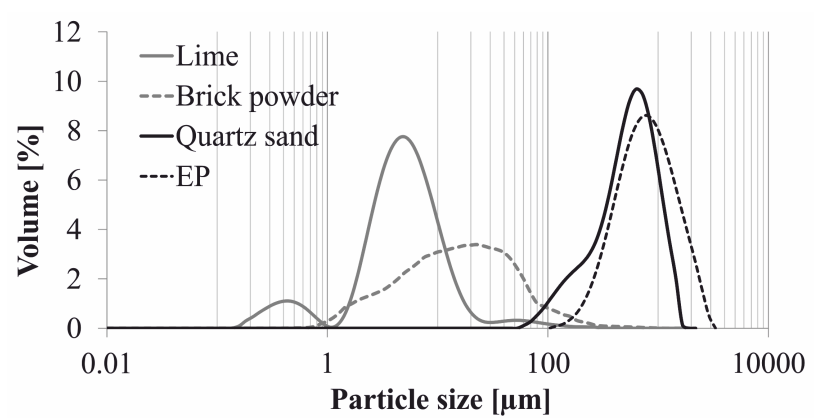

\begin{tabular}{lc}
\hline Property of EP & Value \\
\hline Fraction $[\mathrm{mm}]$ & $0 / 2$ \\
Loose bulk density $\left[\mathrm{kg} \mathrm{m}^{-3}\right]$ & 180 \\
Water absorption $\left[1 \mathrm{~m} \mathrm{~m}^{-3}\right]$ & 350 \\
Thermal conductivity $\left[\mathrm{W} \mathrm{m}^{-1} \mathrm{~K}^{-1}\right]$ & 0.051 \\
Thermostability $\left[{ }^{\circ} \mathrm{C}\right]$ & 900 \\
Compressive strength $[\mathrm{kPa}]$ & 320 \\
$\mathrm{pH}[-]$ & $6-8$ \\
\hline
\end{tabular}

FiguRE 1. Particle size distribution of raw materials and selected properties of expanded perlite.

\begin{tabular}{lccccc}
\hline Mixture & $\begin{array}{c}\text { Hydrated lime } \\
{[\mathrm{g}]}\end{array}$ & $\begin{array}{c}\text { Brick powder } \\
{[\mathrm{g}]}\end{array}$ & $\begin{array}{c}\text { Quartz sand } \\
{[\mathrm{g}]}\end{array}$ & $\begin{array}{c}\text { EP } \\
{[\mathrm{g}]}\end{array}$ & $\begin{array}{c}\mathrm{H}_{2} \mathrm{O} \\
{[\mathrm{ml}]}\end{array}$ \\
\hline REF-L & 100 & - & 400 & - & 120 \\
REF-LB & 50 & 50 & 400 & - & 85 \\
LBP-I & 50 & 50 & - & 50 & 135 \\
LBP-II & 50 & 50 & 12.5 & 37.5 & 125 \\
LBP-III & 50 & 50 & 25 & 25 & 105 \\
LBP-IV & 50 & 50 & 37.5 & 12.5 & 100 \\
\hline
\end{tabular}

TABlE 3. Mortar mixtures composition. 
after 7, 28 and 90 curing days. Flexural and compressive strengths were measured according to EN 1015-11. The water absorption of hardened mortars was determined according to EN 13755 after 28 curing days. Six mortar specimens at least were used to conduct each of the mentioned tests. The porosity of the specimens was assessed using a mercury intrusion porosimetry (MIP). The microstructure images of mortars were obtained by a scanning electron microscope (SEM). Frost resistance tests were performed in accordance with Czech standards ČSN 722452 after 28 curing days. The test required 15 freeze-thaw cycles. One cycle was comprised of $6 \mathrm{~h}$ freezing at $-20^{\circ} \mathrm{C}$ and $12 \mathrm{~h}$ thawing in $20^{\circ} \mathrm{C}$ water. The frost resistance coefficient $D_{f}$ was evaluated as the ratio of flexural strength of samples subjected to 15 freeze-thaw cycles to the flexural strength of non-frozen samples.

\section{Results AND Discussion}

The bulk densities of reference mortars were considerably higher compared to the mortars with EP (figure 22. The reference samples decreased the bulk density due to gradual drying over time. On the other hand, lightweight mortars slightly increased their bulk density over time due to the higher porosity of the samples and their easier carbonation.

The strengths of mortars increased over time because of mortar hardening. The partial replacement of lime by brick waste powder resulted in improvements in the strengths of the mortar, the compressive strength particularly (figure 3). It agrees with the previous observation [12. Hydrated products formed by pozzolanic reaction of the brick powder provided the higher strength of the modified lime mortar. The slightly lower strengths of the REF-L sample were also caused by higher amount of mixing water. The capability of the applied brick waste powder to utilization in lime plasters was thus confirmed. The lightweight samples with EP reached practically the same values of strengths as the reference samples but with the marked reduction in bulk density of the mortars. It can be stated that the strengths of lightweight mortars were almost independent on content of EP (just LBP-II sample showed slightly lower strengths). The effect of EP content on the values of strengths is out of accord to the previous observations on lime-brick powder plasters with expanded clay aggregate, where the strengths decreased with increasing amount of lightweight aggregate [15].

Pore size distribution in the mortar samples, evaluated by MIP, is compared in figure 4. The reference mortars included mainly large capillary pores with radii of $0.3-1 \mu \mathrm{m}$, which is typical of lime mortars. These mortars were evidently less porous than lightweight mortars (see table 4). The use of EP as an aggregate caused dramatically growth in porosity and also changed the pore size distribution in the mortars. The lightweight mortars contained a markedly higher proportion of larger pores with a diameter exceeding
$1 \mu \mathrm{m}$. In all mortars with EP, a second growth of cumulative pore volume is present in an area of pore diameter between 0.01 and $0.1 \mu \mathrm{m}$. These smaller pores are commonly observed in cement mortars; they are formed by the network of CSH [3]. The presence of EP in mortars results in the development of a CSH gel network exhibiting an increased number of these small pores. This is therefore another proof of the pozzolanic reaction of EP with a lime binder. The volume of these pores is slightly higher in LBP-III sample, which may advert to higher content of $\mathrm{CSH}$ phases; this also correlates with the highest values of strengths of this mortar.

The open porosity of mortars (table 4) expectantly enlarged with increasing amount of EP. The water absorption of mortars grew hand-in-hand with increasing open porosity.

The frost resistance of mortars was examined by 15 freeze-thaw cycles; flexural strengths of the mortars were determined after this period and the frost resistance coefficient $\left(D_{f}\right)$ for each mortar was established, table 4. The reference mortar mixtures did not meet the standard criterion of $D_{f}>0.75$ because of their disintegration after 5 freeze-thaw cycles. Only the mortars with adequate ratio of quartz sand and EP (LBP-III and LBP-IV) conformed to the frost resistance standard criterion.

The lime-brick powder mortar with quartz sand/EP mass ratio of 1:1 (LBP-III) was rated, based on its properties, as the best among the studied mortars. For this reason, only the microstructure images of LBP-III mixture are shown in the paper (figure 5). The microstructure of mortar samples was determined at 28 curing days by SEM. In the images, the typical microstructure of expanded perlite is observed - large porous amorphous objects. The crystals of calcite and CSH amorphous phases can be identified in the mortar matrix. The close contact between the mortar matrix and surface of EP in interfacial transition zone (ITZ) is clearly conspicuous in a more detailed image in the center of figure 5 . Image in the right exhibits the formation of products of pozzolanic reaction on the surface of EP.

\section{Conclusions}

The effect of non-hydrophobized expanded perlite (EP) on the mechanical properties, microstructure, and frost resistance of blended lime-brick powder mortars is investigated in this paper. It has been observed that the partial replacement of lime by brick waste powder causes a slightly strength enhancement of mortars and reduces the amount of mixing water. The capability of the applied brick waste powder to utilization in lime plaster was thus confirmed. The application of EP in the mortar mixture is a positive factor: the lightweight samples with EP have practically the same strengths as the reference samples but with the appreciable reduction in bulk density. Expanded perlite significantly changes the pore size distribution in the mortars by 


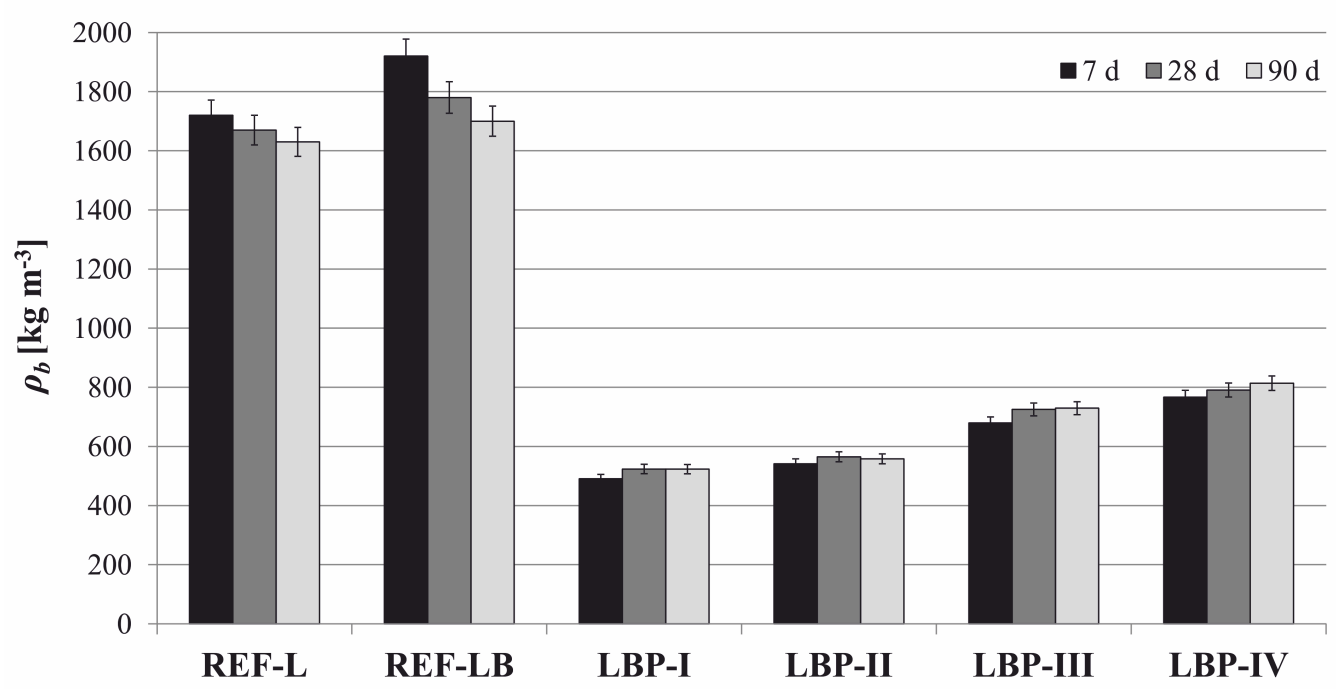

FiguRE 2. Bulk density of mortars over time.

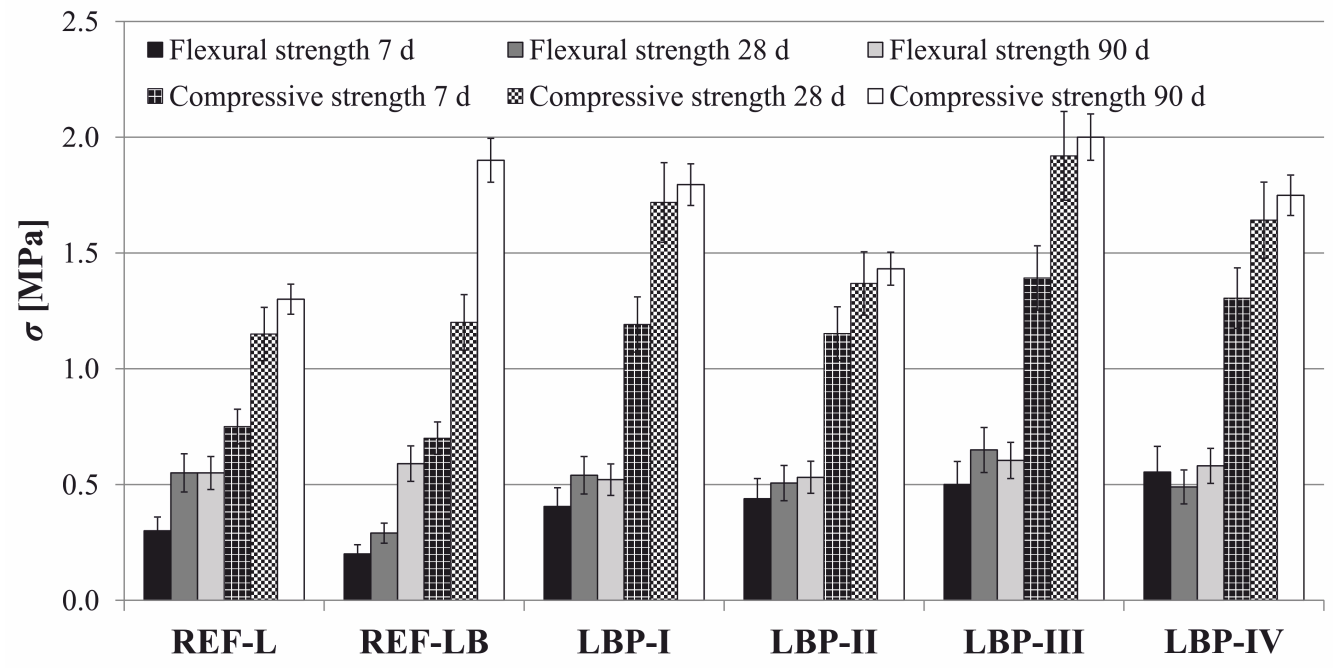

FiguRE 3. Flexural and compressive strength of mortars over time.

\begin{tabular}{lccc}
\hline Mortar mixture & $\begin{array}{c}\text { Open porosity } \\
{[\%]}\end{array}$ & $\begin{array}{c}\text { Water absorption } \\
{[\%]}\end{array}$ & $\begin{array}{c}D_{f} \\
{[-]}\end{array}$ \\
\hline REF-L & 40.2 & 18.0 & - \\
REF-LB & 33.5 & 15.8 & - \\
LBP-I & 63.3 & 66.7 & 0.66 \\
LBP-II & 62.8 & 62.3 & 0.70 \\
LBP-III & 62.2 & 53.5 & 0.97 \\
LBP-IV & 60.1 & 46.4 & 1.02 \\
\hline
\end{tabular}

TABLE 4 . Open porosity, water absorption and frost resistance coefficient $\left(D_{f}\right)$ of mortars. 


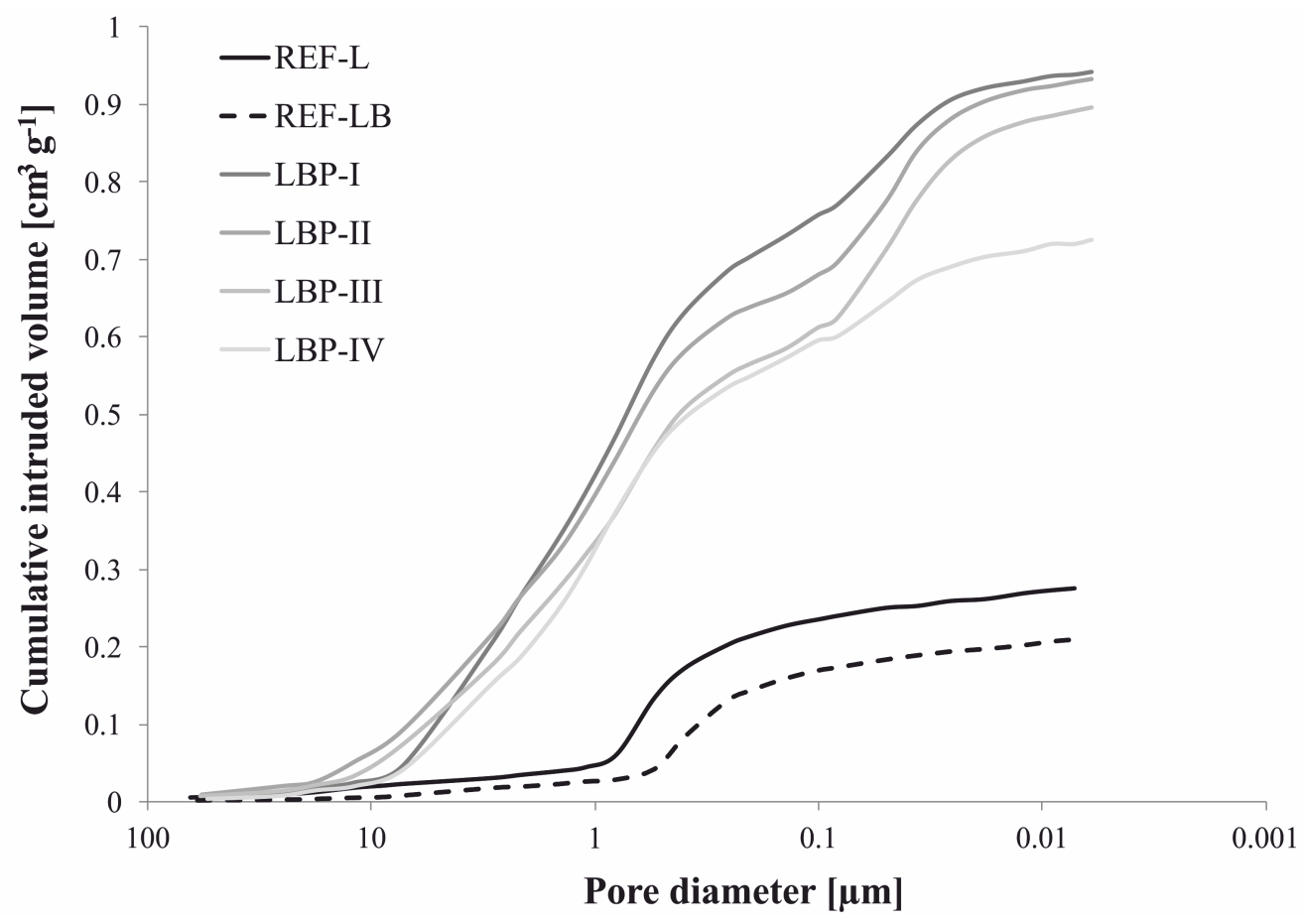

Figure 4. Cumulative volume of pores in mortars after 28 curing days.
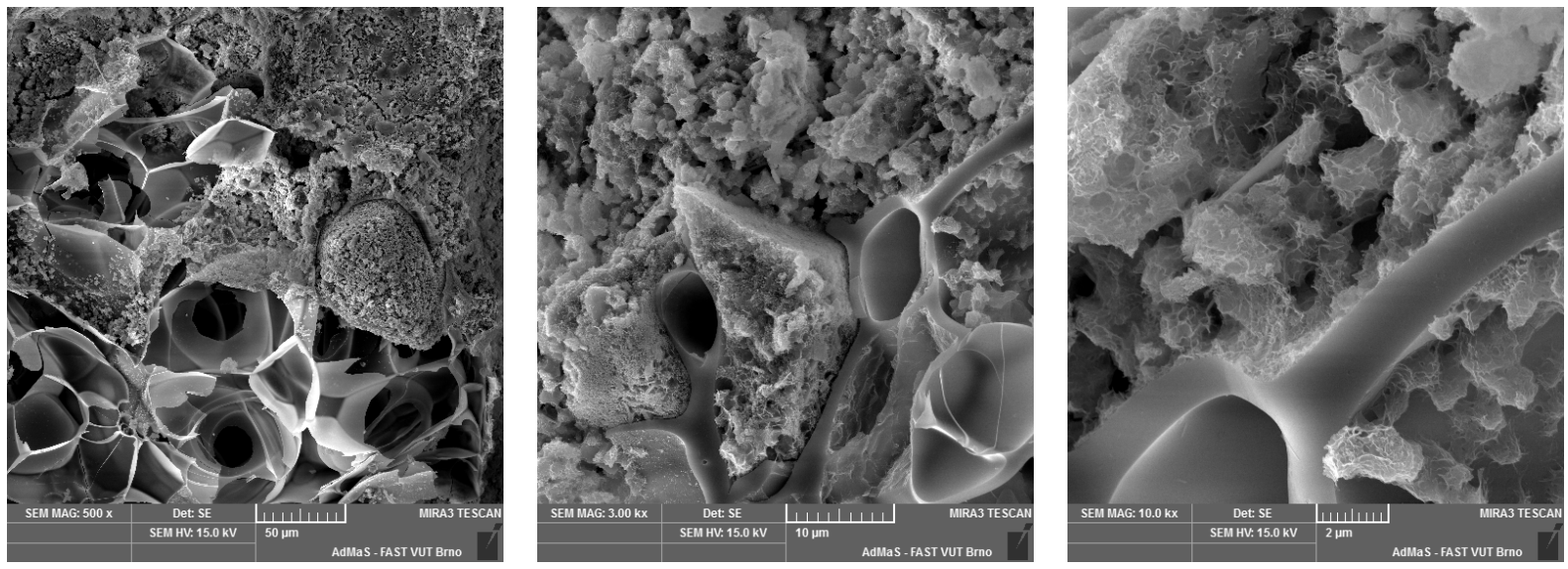

FIGURE 5. SEM images of lightweight mortar LBP-III: left - porous structure of EP in the mortar; in the center - view on interlocking microstructure in the mortar; right - detail of ITZ between mortar matrix and expanded perlite.

the formation of large pores with a diameter between 1 and $10 \mu \mathrm{m}$ and also medium capillary pores formed by the network of CSH. The usage of EP as an aggregate dramatically increases the open porosity of mortars resulted in improvement of their frost resistance. The lime-brick powder mortar with quartz sand/EP mass ratio of 1:1 (LBP-III), which was rated as the best among the studied mortars, has a very good potential for practical applications because its properties are expressly improved, as compared with the common lime render with quartz sand.

\section{ACKNOWLEDGEMENTS}

The work has been achieved with the financial support from the GA ČR research project No. 18-07332S and from the Ministry of Education, Youth and Sports under the
"National Sustainability Programme I" - the project No. LO1408 "AdMaS UP - Advanced Materials, Structures and Technologies".

\section{REFERENCES}

[1] J. L. Clarke. Structural lightweight aggregate concrete. Taylor \& Francis, Oxon, 2005.

[2] A. M. Rashad. A synopsis about perlite as building material - A best practice guide for civil engineer. Construction and Building Materials 121:338-353, 2016. DOI:10.1016/j.conbuildmat.2016.06.001.

[3] L. M. Silva, R. Ribeiro, J. Labrincha, V. Ferreira. Role of lightweight fillers on the properties of a mixed-binder mortar. Cement \&5 Concrete Composites 32:19-24, 2010. DOI:10.1016/j.cemconcomp.2009.07.003

[4] M. Lanzón Torres, P. García-Ruiz. Lightweight pozzolanic materials used in mortars: Evaluation of their 
influence on density, mechanical strength and water absorption. Cement \& Concrete Composites 31:114-119, 2009. DOI:10.1016/j.cemconcomp.2008.11.003.

[5] I. Palomar, G. Barluenga, J. Puentes. Lime-cement mortars for coating with improved thermal and acoustic performance. Construction and Building Materials 75:306-314, 2015. DOI:10.1016/j.conbuildmat.2014.11.012.

[6] S. Barbero, M. Dutto, C. Ferrua, A. Pereno. Analysis on existent thermal insulating plasters towards innovative applications: Evaluation methodology for a real cost-performance comparison. Energy and Buildings 77:40-47, 2014. DOI:10.1016/j.enbuild.2014.03.037

[7] W. Brachaczek. The hydrophobicity of renovation plaster in manufacturing technology optimized by statistical methods. Construction and Building Materials 49:575-582, 2013. DOI:10.1016/j.conbuildmat.2013.08.051.

[8] Z. Pavlík, M. Pavlíková, L. Balík, R. Černý. In-situ analysis of hygric performance of piaristic monastery building. AIP Conference Proceedings 1648:410006, 2015. DOI:10.1063/1.4912635.

[9] P. Brzyski, M. Widomski. The influence of partial replacement of hemp shives by expanded perlite on physical properties of hemp-lime composite. AIP Conference Proceedings 1866:040006, 2017. DOI:10.1063/1.4994486

[10] A. Arizzi, G. Cultrone. Aerial lime-based mortars blended with a pozzolanic additive and different admixtures: A mineralogical, textural and physical-mechanical study. Construction and Building Materials 31:135-143, 2012. DOI:10.1016/j.conbuildmat.2011.12.069.
[11] U. Bulut. Use of perlite as a pozzolanic addition in lime mortars. Gazi University Journal of Science 23:305-313, 2010.

[12] E. Navrátilová, P. Rovnaníková. Pozzolanic properties of brick powders and their effect on the properties of modified lime mortars. Construction and Building Materials 120:530-539, 2016. DOI:10.1016/j.conbuildmat.2016.05.062

[13] M. Čáchová, D. Koňáková, E. Vejmelková, M. Vyšvařil. Ternary binder based plasters with improved thermal insulating ability. IOP Conference Series: Materials Science and Engineering 251:012008, 2017. DOI:10.1088/1757-899X/251/1/012008

[14] M. Čáchová, D. Koňáková, E. Vejmelková, et al. Hygric and mechanical parameters of ternary binder based plasters lightweighted by expanded perlite. IOP Conference Series: Materials Science and Engineering 379:012004, 2018. DOI:10.1088/1757-899X/379/1/012004

[15] M. Vyšvařil, T. Žižlavský, P. Rovnaníková. Rheological and mechanical properties of lime-brick powder mortars with expanded clay aggregate. IOP Conference Series: Materials Science and Engineering 385:012063, 2018. DOI:10.1088/1757-899X/385/1/012063. 